\title{
Two Japanese Corynebacterium ulcerans isolates from the same hospital: ribotype, toxigenicity and serum antitoxin titre
}

\begin{abstract}
Correspondence
Masaaki Iwaki

miwaki@nih.go.jp
\end{abstract}

Received 20 May 2010

Accepted 29 August 2010

\author{
Takako Komiya, ${ }^{1}$ Yukiji Seto, ${ }^{2}$ † Aruni De Zoysa, ${ }^{3}$ Masaaki Iwaki, ${ }^{1}$ \\ Akio Hatanaka, ${ }^{4} \ddagger$ Atsunobu Tsunoda, ${ }^{4} \S$ Yoshichika Arakawa, ${ }^{1}$ \\ Shunji Kozaki ${ }^{2}$ and Motohide Takahashi ${ }^{1}$
${ }^{1}$ Department of Bacteriology II, National Institute of Infectious Diseases, Tokyo, Japan
${ }^{2}$ Infectious Diseases Control, Graduate School of Life and Environmental Sciences, Osaka Prefecture University, Osaka, Japan \\ ${ }^{3}$ Streptococcus and Diphtheria Reference Unit, Respiratory and Systemic Infections Department, \\ Health Protection Agency Centre for Infections, London, UK \\ ${ }^{4}$ Asahi General Hospital, Chiba, Japan
}

Two toxigenic Corynebacterium ulcerans isolates recovered from pharyngeal swabs of two patients from the same hospital in Japan during 2001-2002 were characterized by PFGE and ribotyping. Toxin production in different culture media was examined and serological analysis of patient sera was performed. The two isolates could not be distinguished by PFGE; however, their ribotypes were distinguishable. One of the isolates could represent a novel ribotype. Analysis of toxin production in different culture media demonstrated that the two isolates produced varying amounts of the diphtheria toxin. Serological analysis showed a greater than sevenfold increase in the serum antitoxin titre during the course of infection in one patient.

\section{INTRODUCTION}

Disease caused by Corynebacterium ulcerans is now an emerging threat to human health (CDC, 1997; DeWinter et al., 2005; Kisely et al., 1994; Lartigue et al., 2005; PHLS, 2000; Sing et al., 2005; Von Hunolstein et al., 2003), and has recently been classified as diphtheria by the European Centre for Disease Prevention and Control (http://ecdc. europa.eu/en/healthtopics/pages/diphtheria.aspx). In Japan, the Ministry of Health, Labour and Welfare released notifications concerning this disease twice in 2002 and 2009 , although the disease is not classified as diphtheria in this country.

†Present address: Tochigi Prefectural Livestock Experiment Station, Tochigi, Japan.

$\ddagger$ Present address: Department of Otorhinolaryngology, Tsuchiura Kyodo General Hospital, Ibaraki, Japan.

§Present address: Department of Otolaryngology, Tokyo Medical and Dental University, Tokyo, Japan.

Abbreviations: $\mathrm{CD}_{50}, 50$ \% cytopathic dose; $\mathrm{CDC}$, Centers for Disease Control and Prevention; MRD, minimal reactive dose; PHLS, Public Health Laboratory Service; PLD, phospholipase D; SCIEH, Scottish Centre for Infection and Environmental Health.

A table of primer details and figures of PCR identification and sequence alignment data are available as supplementary material with the online version of this paper.
C. ulcerans is known as a major cause of mastitis in cows. A significant portion of human C. ulcerans infections in the UK has been associated with ingestion of raw dairy products (Galbraith et al., 1982; Hart, 1984; Kisely et al., 1994). This organism has also been recently recognized as a human pathogen associated with companion animals such as dogs and cats (De Zoysa et al., 2005; Dias et al., 2010; Lartigue et al., 2005; SCIEH, 2002; Taylor \& Efstratiou, 2002) and pigs (Schuhegger et al., 2009).

The first case of human infection with toxigenic C. ulcerans was described in 1970 (Fakes \& Downham, 1970) in the UK. In early 2001, 30 years after the first report, the organism was identified as a human pathogen in Japan in a patient who had been feeding 20 cats in and around her home (Hatanaka et al., 2003). The second case in Japan occurred around late 2002, and the two cases occurred in locations about $5 \mathrm{~km}$ apart. Both cases were reported from the same hospital. The first case has already been briefly reported (Hatanaka et al., 2003), but there have been no reports of the second case. No detailed characterization of the isolates or analysis of patient sera has been reported for either of the cases.

Diphtheria caused by Corynebacterium diphtheriae results in a detectable rise in the serum antitoxin titre against diphtheria toxin during the course of infection (Danilova 
et al., 2006). We were interested to know whether toxigenic C. ulcerans would be capable of inducing a similar reaction. In this study, we present the detailed molecular characteristics of the C. ulcerans isolates from the two Japanese cases, and show that a marked increase in serum antitoxin titre occurred during the course of infection in one patient.

\section{METHODS}

Bacterial strains, culture media and standard materials. Bacterial strains used in this study are listed in Table 1. Identification of the strains was performed using an API Coryne kit (bioMérieux). The bacterial strains were cultivated on Loeffler medium (Kyokuto Pharmaceutical Industrial), sheep blood agar plates (Nissui Pharmaceutical), in iron-depleted Pope liquid medium (Tasman \& Van Ramhorst, 1951; Tchorbanov et al., 2004) or brain heart infusion broth (Difco; Becton Dickinson). Japanese national reference diphtheria test toxin lot M59 was used as a control toxin. Japanese national standard diphtheria antitoxin lot 10 , which was calibrated against the World Health Organization international standard antitoxin, was used as a reference material for antitoxin unit definition.

Gram staining and Neisser staining. Gram staining of the bacterial strains was performed using a Gram staining kit (Nissui Pharmaceutical). Neisser staining was performed according to the method originally described by Neisser (Hendrickson \& Krenz, 1991).

PFGE typing. PFGE typing of the bacterial strains was performed essentially according to De Zoysa et al. (1995). The bacterial strains to be analysed were briefly cultured on sheep blood agar plates overnight at $37{ }^{\circ} \mathrm{C}$. The bacterial cells were then collected, embedded in agarose plugs and lysed overnight at $37{ }^{\circ} \mathrm{C}$ using freshly prepared lysis solution (Murray et al., 1990) containing $1 \mathrm{mg}$ lysozyme $\mathrm{ml}^{-1}$. The cells were then treated with proteolysis buffer (Murray et al., 1990) for $48 \mathrm{~h}$ at $37^{\circ} \mathrm{C}$. DNA from the cells embedded in the plugs was subsequently digested with SfiI (New England Biolabs) overnight at $37{ }^{\circ} \mathrm{C}$ and the digested samples were applied to an analytical agarose gel. PFGE was performed in a CHEF DRII apparatus (Bio-Rad) at $11{ }^{\circ} \mathrm{C}$ with a pulse time of 5 to $20 \mathrm{~s}$ for the first $20 \mathrm{~h}$, and then 1 to $5 \mathrm{~s}$ for the following $18 \mathrm{~h}$.

Ribotyping. Ribotyping of bacterial strains was performed as described by De Zoysa et al. (1995) and Regnault et al. (1997). Isolated genomic DNA was digested with BstEII (Roche Diagnostics), electrophoresed in an agarose gel and transferred to HyBond Plus nylon membrane
(Amersham Biosciences). The transferred DNA was hybridized with a DIG-labelled OligoMix 5 probe mixture (Grimont et al., 2004; Regnault et al., 1997), and signals were detected with an alkaline phosphataseconjugated anti-DIG antibody (Roche Diagnostics). Ribotype profiles were analysed using the BioNumerics software program (version 3.0; Applied Maths).

PCR and nucleotide sequence determination. Genomic DNA was isolated from the bacterial strains using a blood mini kit (Qiagen) according to the kit instructions. PCR detection of the diphtheria toxin (tox) gene was performed by amplifying a $248 \mathrm{bp}$ fragment located in the middle of the catalytic domain (A subunit) of the gene using oligonucleotide primers Tox 1 and Tox 2 (Supplementary Table S1 available with the online journal) (Mikhailovich et al., 1995). The phospholipase D (PLD)-encoding gene was detected using primers CorynePLD-F and CorynePLD-R1 (Supplementary Table S1 available with the online journal).

The nucleotide sequence of the tox gene was determined by amplifying five fragments covering the entire ORF (spanning a region upstream as well as downstream of the tox gene) using the primer pairs of DT-1 and Tox 1, Tox 2 and DT-2, DT-3 and Dipht 6R, Dipht 6F and DT-4, and DT-5 and DT-6 (Supplementary Table S1 available with the online journal) (Mikhailovich et al., 1995; Nakao et al., 1996). Nucleotide sequences of the amplified fragments were determined by cycle sequencing using a BigDye terminator kit (Applied Biosystems) and analysed using an Applied Biosystems model 310 genetic analyser.

Toxigenicity assays. Immunological detection of diphtheria toxin was performed using a further modification of the modified Elek method (Reinhardt et al., 1998). A $9 \mathrm{~mm}$ well was made aseptically on an agar plate containing 20 g proteose peptone $1^{-1}$ (Becton Dickinson), $1 \mathrm{~g}$ Bacto yeast extract $\mathrm{l}^{-1}$ (Becton Dickinson), $2.5 \mathrm{~g} \mathrm{NaCl}^{-1}, 20 \%$ (v/v) newborn calf serum (Gibco; Life Technologies) and $15 \mathrm{~g}$ Bacto agar $1^{-1}$ (Becton Dickinson). The bacterial strains to be tested were then inoculated at a distance of $10 \mathrm{~mm}$ from the edge of the well, which was then filled with an aqueous solution containing 4.5 units of standard diphtheria antitoxin. The precipitin lines formed were observed after 1 to 2 days of cultivation at $37^{\circ} \mathrm{C}$.

For Vero cell and rabbit skin toxigenicity tests (Miyamura et al., $1974 \mathrm{a}, \mathrm{b})$, the liquid condensed at the base of the Loeffler slant ('Loeffler condensation') and the culture supernatant of the Pope liquid medium ('Pope culture supernatant') were sterile filtered and used as specimens. Serially diluted specimens were added to Vero cells seeded in 96-well culture plates, and the neutralization end points were determined by observing cytotoxic effects 4 days post-incubation, as described by Miyamura et al. (1974a, b). Standard antitoxin

Table 1. Bacterial isolates and strains used in this study

\begin{tabular}{|c|c|c|c|c|c|}
\hline \multirow[t]{2}{*}{ Isolate and strain no. } & \multicolumn{3}{|c|}{ Patient source } & \multirow[t]{2}{*}{ Clinical symptom } & \multirow[t]{2}{*}{ Reference } \\
\hline & Sex & Age & Site of isolation & & \\
\hline Corynebacterium ulcerans 0102 & $\mathrm{~F}$ & 52 & Throat (pseudomembrane) & Dyspnoea, fever & Hatanaka et al. (2003) \\
\hline Corynebacterium ulcerans 0211 & M & 54 & Throat (pseudomembrane) & Sore throat, fever & This study \\
\hline Corynebacterium ulcerans ATCC 51799 & - & - & - & - & ATCC \\
\hline Corynebacterium diphtheriae PW8 & - & - & - & - & Laboratory stock \\
\hline Corynebacterium diphtheriae ATCC 700971 & - & - & - & - & ATCC (NCTC 13129) \\
\hline Rhodococcus equi ATCC 6939 & - & - & - & - & ATCC \\
\hline Citrobacter koseri CIP 105177 & - & - & - & - & CIP \\
\hline
\end{tabular}

ATCC, American Type Culture Collection; CIP, Collection de l'Institut Pasteur; F, female; M, male; NCTC, National Collection of Type Cultures; PW8, Park-Williams no. 8. 
(40 $\mathrm{IU} \mathrm{ml} \mathrm{m}^{-1}$ ) was used to confirm that the toxicity was due to diphtheria toxin.

For the rabbit skin toxigenicity test, specimens were appropriately diluted in PBS containing $0.2 \%$ gelatin, and $100 \mu \mathrm{l}$ of this solution were intradermally injected into the shaved back of a female Japanese white rabbit weighing $3.5 \mathrm{~kg}$. The diameter of local erythema formed was measured on day 2 post-injection. Standard antitoxin (1 IU $\mathrm{ml}^{-1}$ ) was used to confirm that the toxicity was due to diphtheria toxin. Animal experiments were performed with the approval of the Animal Experiment Committee of the National Institute of Infectious Diseases. PLD activity was visualized by enhanced haemolysis on sheep blood agar plates when C. ulcerans isolates and Rhodococcus equi ATCC 6939 were streaked close to each other on the plates.

Serum antitoxin titre determination. Anti-diphtheria toxin neutralization titre was determined by the Vero cell cytotoxicity assay described above. Serially diluted patient serum or standard antitoxin was mixed with $16 \mathrm{CD}_{50} \mathrm{ml}^{-1}$ [i.e. (16 times the $\mathrm{CD}_{50}$ ) $\mathrm{ml}^{-1}$ ] of the reference diphtheria test toxin and added to the Vero cell cultures (Miyamura et al., 1974a). The antitoxin titre of patient sera was determined by comparing the neutralization end points of the patient sera and standard antitoxin, and was expressed in IU.

\section{RESULTS}

\section{Cases}

The first case has been reported previously (Hatanaka et al., 2003). Briefly, the patient was a 52-year-old woman who presented to the Asahi General Hospital in Chiba Prefecture, Japan, on 16 February 2001, with dyspnoea and a sore throat. C. ulcerans was isolated from a pharyngeal pseudomembrane. She recovered without any serious sequelae following erythromycin treatment. The strain 0102 was isolated from this patient.

The second case was a 54-year-old man who presented to the same hospital with a sore throat and fever on 28 October 2002. C. ulcerans was isolated from a yellow-white pseudomembrane observed in his pharynx and was designated 0211. $\mathrm{He}$ recovered without any serious sequelae following clarithromycin treatment. No contact with dairy livestock, raw dairy products or domestic animals was reported.

\section{Identification of the isolates}

Bacteriological characteristics of the two C. ulcerans isolates are summarized in Table 2. Both strains exhibited Grampositive short rod morphology on Gram staining. Clearly distinguishable metachromatic granules were observed at the ends of the cells by Neisser staining (Hendrickson \& Krenz, 1991). Both strains were biochemically characterized as C. ulcerans with a probability of $99.7 \%$ using the API Coryne kit (code 0111326).

\section{Genotyping of the isolates}

PFGE patterns are shown in Fig. 1(a). The PFGE patterns of isolates 0102 and 0211 are indistinguishable, whereas the pattern for C. ulcerans ATCC 51799 is clearly different from that for the Japanese isolates. The ribotype profiles of the two isolates are shown in Fig. 1(b), and comparison by cluster analysis of these profiles with that of the C. ulcerans ribotypes in an in-house database (De Zoysa et al., 2005) revealed that the ribotype profile of isolate 0102 showed $100 \%$ similarity with ribotype U4, which is a predominant profile seen among human clinical C. ulcerans isolates in the UK. The ribotype profile of isolate 0211 did not match with any of the known C. ulcerans ribotypes (U1-U9), suggesting that it could potentially be a new ribotype (Fig. 1c).

\section{Toxigenicity tests}

The presence of the tox gene in both isolates was demonstrated by PCR using oligonucleotide primers Tox 1 and Tox 2 (Supplementary Table S1 available with the online journal) (Mikhailovich et al., 1995) to detect a $248 \mathrm{bp}$ amplified fragment corresponding to the middle of the catalytic domain (A subunit) of the diphtheria toxin gene. The tox gene was detected in both strains (Table 2).

Table 2. Bacteriological characteristics of the isolates

\begin{tabular}{|lcc|}
\hline \multirow{2}{*}{ Test } & & Isolate \\
\cline { 2 - 3 } & $\mathbf{0 1 0 2}$ & $\mathbf{0 2 1 1}$ \\
\hline Gram staining & Gram positive & Gram positive \\
Metachromatic granules by Neisser staining & + & + \\
Identification by API Coryne kit & C. ulcerans $(99.7 \%$; code 0111326$)$ & C. ulcerans (99.7\%; code 0111326) \\
Toxigenicity & + & + \\
tox gene PCR & + & ND \\
Elek assay & + & + \\
PLD & + & + \\
pld gene PCR & + & \\
$R$. equi-stimulated haemolysis & + & \\
\hline
\end{tabular}

ND, Not detectable. 
(a)

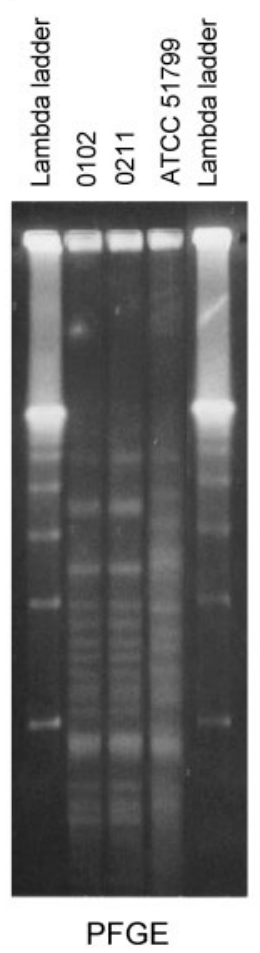

(b)

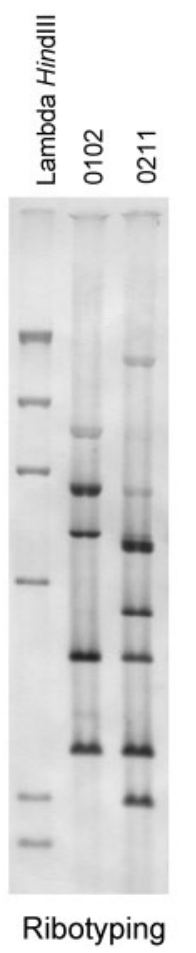

(c)

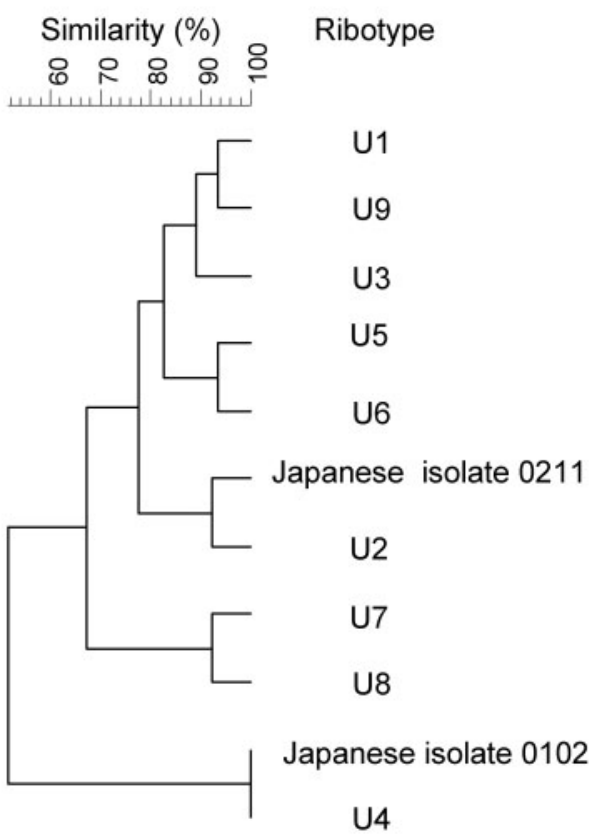

Dendrogram showing cluster analysis of ribotypes

Fig. 1. PFGE and ribotype patterns of the isolates. (a) PFGE patterns. Genomic DNA of C. ulcerans clinical isolates 0102 and 0211 and of C. ulcerans ATCC 51799 was digested with Sfil and subjected to PFGE as described in Methods. Lambda phage DNA ladders were used as molecular mass markers. (b) Ribotype patterns of the clinical isolates. Genomic DNA of C. ulcerans clinical isolates 0102 and 0211 were digested with BstEll and subjected to agarose gel electrophoresis and Southern blotting as described in Methods. Lambda Hindlll-digested DNA was used as a molecular mass marker. (c) Cluster analysis of ribotypes. Similarity between ribotyping band patterns of the clinical isolates were compared with those of nine known ribotypes (U1-U9), which were calculated according to the UPGMA method.

The sizes of the amplified fragments were indistinguishable from each other and from a DNA fragment amplified from genomic DNA of $C$. diphtheriae vaccine strain PW8 by agarose gel electrophoresis (data not shown).

Immunological detection of diphtheria toxin was performed using the modified Elek method (Reinhardt et al., 1998). A precipitin line was observed for isolate 0102 but isolate 0211 did not exhibit a clearly observable precipitin line on the Elek plate, suggesting that the amount of toxin produced by isolate 0211 in this culture medium was less than that produced by isolate 0102 .

The activity of the toxin produced by the isolates was then measured using Vero cell and rabbit skin toxigenicity tests according to Miyamura et al. (1974a). Loeffler condensation of isolate 0102 exhibited $513 \mathrm{CD}_{50} \mathrm{ml}^{-1}$ of cytotoxicity based on the Vero cell test, and the toxicity was completely neutralized by $40 \mathrm{IU} \mathrm{ml})^{-1}$ (1 IU per culture well) of diphtheria antitoxin (Table 3 ). In contrast, Loeffler condensation of isolate 0211 showed approximately twofold less cytotoxicity $\left(208 \mathrm{CD}_{50} \mathrm{ml}^{-1}\right)$ but neutralization by the same concentration of antitoxin was only partial, retaining $114 \mathrm{CD}_{50} \mathrm{ml}^{-1}$ (Table 3). Because $C$. diphtheriae vaccine strain PW8 showed $2 \times 10^{4} \mathrm{CD}_{50} \mathrm{ml}^{-1}$ and this activity was completely neutralized by the same concentration of antitoxin, the partial neutralization observed for 0211 was not thought to be caused by insufficient serum antitoxin titre.

Toxin activity was also detectable by the rabbit skin toxigenicity test (Miyamura et al., 1974a). Loeffler condensation of isolate 0102 contained $80 \mathrm{MRD} \mathrm{ml}^{-1}$ [i.e. ( 80 times the MRD) $\mathrm{ml}^{-1}$ ] of activity. In contrast to the results from the Vero cell assay, $20 \mathrm{MRD} \mathrm{ml}{ }^{-1}$ of this activity remained unneutralized after treatment with $1 \mathrm{IU}$ standard diphtheria antitoxin $\mathrm{ml}^{-1}$ (Table 3). The condensation of isolate 0211 showed less activity ( $20 \mathrm{MRD} \mathrm{ml}^{-1}$ ), which was neutralized incompletely by the antitoxin (Table 3 ).

C. ulcerans strains are known to produce another toxic factor PLD. The presence of the PLD-encoding gene and secretion of the active enzyme (visualized by crossstreaking with $R$. equi ATCC 6939) occurred in both isolates (Supplementary Fig. S1 available with the online journal). PLD may be an additional factor contributing to 
Table 3. Toxicity of C. ulcerans assessed by Loeffler condensation and Pope culture supernatant

Assays were done in duplicate and repeated three times (Vero cytotoxicity) or once (rabbit erythema).

\begin{tabular}{|c|c|c|c|c|c|c|}
\hline & \multicolumn{2}{|c|}{ C. ulcerans } & $\frac{\text { C. diphtheriae }}{\text { PW8 }}$ & \multicolumn{2}{|c|}{ C. ulcerans } & $\frac{\text { C. diphtheriae }}{\text { PW8 }}$ \\
\hline \multicolumn{7}{|c|}{ Vero cytotoxicity $\left(\mathrm{CD}_{50} \mathrm{ml}^{-1}\right)$} \\
\hline Before neutralization & $513 \pm 238^{*}$ & $208 \pm 50^{*}$ & $2.0 \times 10^{4} \dagger$ & $640 \dagger$ & $1.4 \pm 0.006 \times 10^{4 \star}$ & $3.9 \pm 0.02 \times 10^{5 *}$ \\
\hline Before neutralization & $80(40,160) \S$ & 2011 & $2.0 \times 10^{4} \mathrm{II}$ & $640 \|$ & $\begin{array}{c}1.6 \times 10^{4}\left(8.0 \times 10^{3}\right. \\
\left.3.2 \times 10^{4}\right) \S\end{array}$ & $2.0 \times 10^{4} \mathrm{II}$ \\
\hline After neutralizationll & 209 & $10 \mathrm{~s}$ & ND & ND & ND & ND \\
\hline
\end{tabular}

ND, Not detectable.

${ }^{\star}$ Mean \pm SE.

$\dagger$ The same results were obtained in three repeats.

$\$$ Neutralization with $40 \mathrm{IU}$ diphtheria antitoxin $\mathrm{ml}^{-1}$.

$\S$ Geometric mean of a duplicate assay. Lower and higher values are indicated in parentheses.

IIThe same results were obtained in a duplicate assay.

SNeutralization with $1 \mathrm{IU}$ diphtheria antitoxin $\mathrm{ml}^{-1}$.

unneutralized cytotoxicity of Vero cells and to erythema formation on rabbit skin.

\section{Nucleotide sequences of the tox genes}

We then determined the nucleotide sequence of five fragments covering the entire tox gene and its flanking regions by amplifying these with the primer pairs shown in Supplementary Table S1 (available with the online journal) (Mikhailovich et al., 1995; Nakao et al., 1996). The alignment of the nucleotide sequences of the tox genes in C. ulcerans isolates 0102 and 0211 , and C. diphtheriae PW8, is shown in Supplementary Fig. S2 (available with the online journal). The sequences from isolates 0102 (GenBank/ EMBL/DDBJ accession no. AB304278) and 0211 were identical to each other and to that of the German $C$. ulcerans isolate A6361 (Sing et al., 2003). In addition, the nucleotide sequence of the upstream region, as determined by sequencing of DNA fragments amplified with primers DT-1 and Tox 1 (Supplementary Table S1 available with the online journal), were identical to each other.

The tox gene of isolates 0102 and 021 showed a difference of $81 \mathrm{nt}$ (corresponding to 27 amino acids) compared with that of the strain PW8 (Supplementary Fig. S2 available with the online journal). The major difference between the C. ulcerans toxin and PW8-derived toxin was observed in the receptorbinding domain in the B subunit of the toxin molecule.

\section{Dependence of toxin production on culture medium}

In contrast to the identity in tox gene sequences, the two isolates differed in terms of the effect of culture conditions on toxin production. Toxin production by the two $C$. ulcerans isolates on the Loeffler medium and in irondepleted Pope liquid medium, a medium frequently used for diphtheria toxin production (Tasman \& Van Ramhorst, 1951; Tchorbanov et al., 2004), were compared (Table 3). A large difference was observed between the two C. ulcerans isolates in their response to culture media (Table 3). Strain 0211 exhibited a more than 70-fold difference in Vero cell cytotoxicity when cultured in the different media $\left(208 \mathrm{CD}_{50}\right.$ $\mathrm{ml}^{-1}$ for Loeffler condensation and $14000 \mathrm{CD}_{50} \mathrm{ml}^{-1}$ for Pope culture supernatant). In contrast, strain 0102 showed a less than twofold difference in cytotoxic activity between the Loeffler medium and Pope medium $\left(513 \mathrm{CD}_{50} \mathrm{ml}^{-1}\right.$ for Loeffler condensation and $640 \mathrm{CD}_{50} \mathrm{ml}^{-1}$ for Pope culture supernatant), suggesting that the two strains do not share a common mechanism for regulating toxin activity. The strains also differed in the rabbit skin toxigenicity test. Strain 0211 exhibited an erythema forming activity at $20 \mathrm{MRD}$ when cultured on Loeffler medium and 800-fold more activity $\left(1.6 \times 10^{4} \mathrm{MRD} \mathrm{ml} \mathrm{m}^{-1}\right)$ in Pope medium; these results are comparable to that of $C$. diphtheriae vaccine strain PW8. In contrast, strain 0102 showed only an eightfold difference in its ability to induce erythema formation ( $80 \mathrm{vs}$ $640 \mathrm{MRD} \mathrm{ml}^{-1}$ on Loeffler medium and Pope medium, respectively).

The product of the $d t x R$ gene is an important factor regulating $C$. diphtheriae diphtheria toxin gene expression in response to the iron content in culture media (Boyd et al., 1990). In the two C. ulcerans strains, the $d t x R$ gene was detectable by Southern blotting (Fig. 2). In strain 0102, the nucleotide sequence of the $d t x R$ gene (including its $5^{\prime}$ and $3^{\prime}$-flanking regions) amplified with the primers listed in Supplementary Table S1 (available with the online journal) was identical to reported sequences (data not 


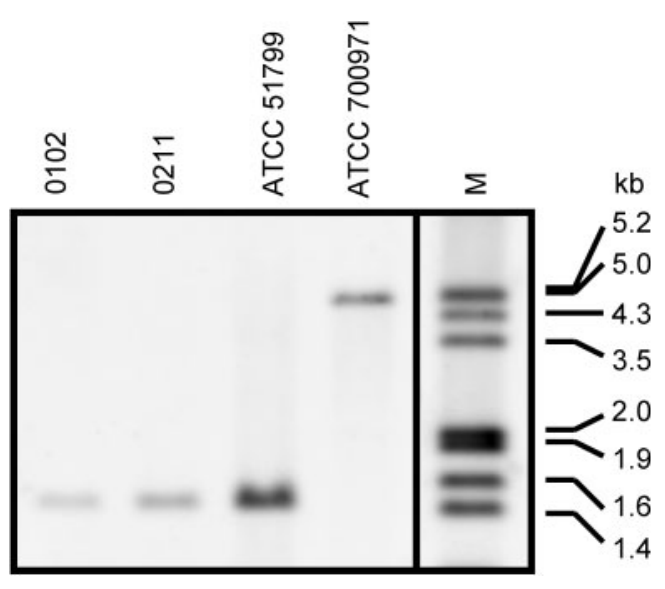

Fig. 2. Presence of the $d t x R$ gene in the clinical isolates. Genomic DNA from C. ulcerans 0102 and 0211, ATCC 51799 and C. diphtheriae ATCC 700971 (equivalent to NCTC 13129) was digested with HindIII and was subjected to Southern blotting and detected using a DIG-labelled $d t x R$ probe. $M$ represents lambda EcoRI-Hindlll digested DNA, which was used as a molecular mass marker.

shown) (Boyd et al., 1990). However, for strain 0211, amplification of the region was not possible, suggesting a difference in nucleotide sequences in at least one of the primer regions flanking the $d t x R$ gene, which could affect the isolate's toxin production in response to culture conditions.

\section{Serum antitoxin titre}

Respiratory infection with toxigenic $C$. diphtheriae is known to cause elevation of serum antitoxin during the course of infection (Danilova et al., 2006); however, it is not yet clear if $C$. ulcerans respiratory infection can cause such an elevation. From the second case reported in our study (in which strain 0211 was isolated), patient serum was obtained periodically from the time of first presentation to the hospital on 28 October 2002 until 16 February 2005. The diphtheria antitoxin titre was measured by Vero cell neutralization assay (Miyamura et al., 1974a) using Japanese national standard diphtheria antitoxin lot 10 as a reference (Table 4). The vaccination history of the patient was unclear. At first presentation to the hospital, the serum antitoxin titre was undetectable. However, the antitoxin titre started to increase 2 weeks thereafter $\left(0.39 \mathrm{IU} \mathrm{ml}^{-1}\right)$ and rapidly rose to almost $2.5 \mathrm{IU} \mathrm{ml}^{-1}$ within a further 3 weeks. The high antibody titre was retained until at least the last sampling date (more than 2 years later). The fully protective level of antitoxin titre against diphtheria is believed to be $0.1 \mathrm{IU} \mathrm{ml}^{-1}$ (Galazka, 1993; Hasselhorn et al., 1998). This result indicates that human respiratory $C$. ulcerans infection can induce an antibody response against diphtheria toxin, as well as in the reported cases of $C$. diphtheriae infection (Danilova et al., 2006), and that the
Table 4. Serum antitoxin titre from the second case

All assays were done in triplicate and repeated three times, twice or once.

\begin{tabular}{|c|c|}
\hline Date & Titre $\left(\mathrm{IU} \mathrm{ml} \mathbf{~}^{-1}\right)$ \\
\hline 28 October 2002 & ND \\
\hline 11 November 2002 & $0.39 \pm 0.06^{*}$ \\
\hline 2 December 2002 & $2.47 \pm 0.00^{*}$ \\
\hline 14 April 2003 & $2.72 \pm 0.05^{*}$ \\
\hline 24 December 2003 & $1.18 \dagger$ \\
\hline 16 February 2005 & $0.92 \ddagger$ \\
\hline
\end{tabular}

ND, Not detectable.

${ }^{*}$ Values are the mean $\pm \mathrm{SE}$; assays were repeated three times.

$\dagger$ Repeated assays gave the same results; assays were repeated twice.

$\ddagger$ The same results were obtained in triplicate; assays were repeated once.

rise in antibody titre can be utilized as a marker of $C$. ulcerans infection.

\section{DISCUSSION}

In the present study, two toxigenic C. ulcerans isolates recovered from pharyngeal swabs were characterized. The two isolates were indistinguishable by PFGE but could be distinguished by ribotyping. The isolate 0211 , isolated in 2002 , could potentially represent a new ribotype that has not been seen in Europe or North America. Geographically specific distribution has already been reported for some $C$. ulcerans ribotypes (De Zoysa et al., 2005). Whether this new ribotype is specific to the Asian region or not will be clarified with further collection of clinical isolates from this region.

In the 2002 case, the patient showed a marked increase in serum antitoxin titre during the course of infection, which is, to our knowledge, the first evidence for such an increase in a C. ulcerans respiratory case. The patient showed a remarkable increase in titre within 2 weeks after he had first presented to the hospital, and the elevated titre remained for more than 2 years at least. Whether this rapid and lasting antibody response was based on previous vaccination is not clear, because insufficient information was available on the vaccination history of the patient. An increase in serum antitoxin titre during cutaneous infection caused by $C$. ulcerans has also been reported by Wagner et al. (2001).

Analysis in different culture media showed that the two isolates exhibited varying degrees of toxin activity (Table 3 ). First, for both isolates the toxin activities in Loeffler condensation were not completely neutralized by diphtheria antitoxin. The deduced amino acid sequence of their tox gene product was different from that of $C$. diphtheriae PW8 by 28 amino acid residues, mainly in the receptorbinding domain of the toxin molecule. However, it is not likely that the difference could account for the incomplete neutralization. When cultured in Pope liquid medium, 
both isolates showed higher toxin activity than in Loeffler condensation, and the activity was completely neutralized by the same antitoxin. This suggests that, in addition to the tox gene product, on Loeffler medium the C. ulcerans isolates could secrete toxic substances immunologically discrete from the tox gene product, including PLD. In contrast, in Pope medium, the major part of toxicity could be attributed to their tox gene products.

Another feature varying between the two isolates was the response to culture conditions. The 0211 isolate responded well to the change of culture conditions. In contrast, the response of 0102 was not remarkable. This indicates that the isolates do not share the same mechanism for the regulation of toxin activity, even though the nucleotide sequence of the upstream region of the tox gene was identical in these isolates, as determined by the sequencing of DNA fragments obtained by PCR with primers DT-1 and Tox 1.

Concerning the regulatory gene $d t x R$, the presence of the gene was demonstrated in both isolates by the Southern hybridization experiment. However, for isolate 0211, the nucleotide sequence of the gene could not be determined because amplification of DNA fragments spanning from the upstream region to the $\mathrm{N}$-terminal region of the ORF was impossible with primers dtxRprimerF\#6 and dtxRprimerR\#2 (Supplementary Table S1 available with the online journal) designed based on the reported nucleotide sequence (Boyd et al., 1990). Within this region there might be some significant difference in nucleotide sequence that remains to be elucidated, which affects the regulation of tox gene regulation.

Mass immunization against diphtheria, as well as tetanus and pertussis, has been conducted in many countries for decades with diphtheria toxoid. With the increasing importance of C. ulcerans human infection, immunization with toxoid and therapy with diphtheria antitoxin are considered to be effective against the disease (CDC, 1997; De Zoysa et al., 2005; Tiwari et al., 2008; Von Hunolstein et al., 2003). In the present paper we have shown that serum from a patient was able to neutralize diphtheria toxin at a high titre. Our data also suggest that cross protection between $C$. diphtheriae and C. ulcerans infections would be possible.

\section{ACKNOWLEDGEMENTS}

We thank Yoshiaki Nagaoka for excellent experimental support in animal manipulation. This work was supported in part by Health and Labour Sciences research grants (Research on Emerging and Reemerging Infectious Diseases and Research on Pharmaceutical and Medical Safety, H19-Shinkou-Ippan-009).

\section{REFERENCES}

Boyd, J., Oza, M. N. \& Murphy, J. R. (1990). Molecular cloning and DNA sequence analysis of a diphtheria tox iron-dependent regulatory element $(d t x R)$ from Corynebacterium diphtheriae. Proc Natl Acad Sci U S A 87, 5968-5972.

CDC (1997). Respiratory diphtheria caused by Corynebacterium ulcerans - Terre Haute, Indiana, 1996. MMWR Morb Mortal Wkly Rep 46, 330-332.

Danilova, E., Jenum, P. A., Skogen, V., Pilinikov, V. F. \& Sjursen, H. (2006). Antidiphtheria antibody responses in patients and carriers of Corynebacterium diphtheriae in the Arkhangelsk region of Russia. Clin Vaccine Immunol 13, 627-632.

DeWinter, L. M., Bernard, K. A. \& Romney, M. G. (2005). Human clinical isolates of Corynebacterium diphtheriae and Corynebacterium ulcerans collected in Canada from 1999 to 2003 but not fitting reporting criteria for cases of diphtheria. J Clin Microbiol 43, 34473449.

De Zoysa, A., Efstratiou, A., George, R. C., Jahkola, M., Vuopio-Varkila, J., Deshevoi, S., Tseneva, G. Y. \& Rikushin, Y. (1995). Molecular epidemiology of Corynebacterium diphtheriae from northwestern Russia and surrounding countries studied by using ribotyping and pulsed-field gel electrophoresis. J Clin Microbiol 33, 1080-1083.

De Zoysa, A., Hawkey, P. M., Engler, K., George, R., Mann, G., Reilly, W., Taylor, D. \& Efstratiou, A. (2005). Characterization of toxigenic Corynebacterium ulcerans strains isolated from humans and domestic cats in the United Kingdom. J Clin Microbiol 43, 4377-4381.

Dias, A. A. S. O., Silva, F. C., Pereira, G. A., Souza, M. C., Camello, T. C. F., Damasceno, J. A. L. D., Pacheco, L. G. C., Miyoshi, A., Azevedo, V. A. \& other authors (2010). Corynebacterium ulcerans isolated from an asymptomatic dog kept in an animal shelter in the metropolitan area of Rio de Janeiro, Brazil. Vector Borne Zoonotic Dis (in press). doi: 10.1089/vbz.2009.0132.

Fakes, R. W. \& Downham, M. (1970). Toxic reaction to Corynebacterium ulcerans. Lancet I, 298.

Galazka, A. M. (1993). Module 2: Diphtheria, WHO/EPI/GEN/93.12. Geneva: World Health Organization.

Galbraith, N. S., Forbes, P. \& Clifford, C. (1982). Communicable disease associated with milk and dairy products in England and Wales 1951-80. Br Med J (Clin Res Ed) 284, 1761-1765.

Grimont, P. A. D., Grimont, F., Efstratiou, A., De Zoysa, A., Mazurova, I. K., Ruckly, C., Lejay-Collin, M., Martin-Delautre, S., Regnault, B. \& other authors (2004). International nomenclature for Corynebacterium diphtheriae ribotypes. Res Microbiol 155, 162-166.

Hart, R. J. C. (1984). Corynebacterium ulcerans in humans and cattle in North Devon. J Hyg (Camb) 92, 161-164.

Hasselhorn, H.-M., Nübling, M., Tiller, F. W. \& Hofmann, F. (1998). Factors influencing immunity against diphtheria in adults. Vaccine 16, $70-75$.

Hatanaka, A., Tsunoda, A., Okamoto, M., Ooe, K., Nakamura, A., Miyakoshi, M., Komiya, T. \& Takahashi, M. (2003). Corynebacterium ulcerans diphtheria in Japan. Emerg Infect Dis 9, 752-753.

Hendrickson, D. A. \& Krenz, H. J. (1991). Reagents and stains. In Manual of Clinical Microbiology, 5th edn, pp. 1289-1314. Edited by A. Balows, W. J. J. Hausler, K. L. Herrmann, H. D. Isenberg \& H. J. Shadomy. Washington, DC: American Society for Microbiology.

Kisely, S. R., Proce, S. \& Ward, T. (1994). 'Corynebacterium ulcerans': a potential cause of diphtheria. Commun Dis Rep CDR Rev 4, R63R64.

Lartigue, M.-F., Monnet, X., Le Flèche, A., Grimont, P. A. D., Benet, J.-J., Durrbach, A., Fabre, M. \& Nordmann, P. (2005). Corynebacterium ulcerans in an immunocompromised patient with diphtheria and her dog. J Clin Microbiol 43, 999-1001.

Mikhailovich, V. M., Melnikov, V. G., Mazurova, I. K., Wachsmuth, I. K., Wenger, J. D., Wharton, M., Nakao, H. \& Popovic, T. (1995). 
Application of PCR for detection of toxigenic Corynebacterium diphtheriae strains isolated during the Russian diphtheria epidemic, 1990 through 1994. J Clin Microbiol 33, 3061-3063.

Miyamura, K., Tajiri, E., Ito, A., Murata, R. \& Kono, R. (1974a). Micro cell culture method for determination of diphtheria toxin and antitoxin titres using VERO cells. II. Comparison with the rabbit skin method and practical application for seroepidemiological studies. J Biol Stand 2, 203-209.

Miyamura, K., Nishio, S., Ito, A., Murata, R. \& Kono, R. (1974b). Micro cell culture method for determination of diphtheria toxin and antitoxin titres using VERO cells. I. Studies on factors affecting the toxin and antitoxin titration. J Biol Stand 2, 189-201.

Murray, B. E., Singh, K. V., Heath, J. D., Sharma, B. R. \& Weinstock, G. M. (1990). Comparison of genomic DNAs of different enterococcal isolates using restriction endonucleases with infrequent recognition sites. J Clin Microbiol 28, 2059-2063.

Nakao, H., Pruckler, J. M., Mazurova, I. K., Narvskaia, O. V., Glushkevich, T., Marijevski, V. F., Kravetz, A. N., Fields, B. S., Wachsmuth, I. K. \& other authors (1996). Heterogeneity of diphtheria toxin gene, tox, and its regulatory element, $d t x R$, in Corynebacterium diphtheriae strains causing epidemic diphtheria in Russia and Ukraine. J Clin Microbiol 34, 1711-1716.

PHLS (2000). Three cases of toxigenic Corynebacterium ulcerans infection. Commun Dis Rep CDR Wkly 10, 52.

Regnault, B., Grimont, F. \& Grimont, P. A. D. (1997). Universal ribotyping method using a chemically labelled oligonucleotide probe mixture. Res Microbiol 148, 649-659.

Reinhardt, D. J., Lee, A. \& Popovic, T. (1998). Antitoxin-in-membrane and antitoxin-in-well assays for detection of toxigenic Corynebacterium diphtheriae. J Clin Microbiol 36, 207-210.

Schuhegger, R., Schoerner, C., Dlugaiczyk, J., Lichtenfeld, I., Trouillier, A., Zeller-Peronnet, V., Busch, U., Berger, A., Kugler, R. $\&$ other authors (2009). Pigs as source for toxigenic Corynebacterium ulcerans. Emerg Infect Dis 15, 1314-1315.
SCIEH (2002). Toxigenic Corynebacterium ulcerans in cats. SCIEH Weekly Rep 36, 69-75.

Sing, A., Hogardt, M., Bierschenk, S. \& Heesemann, J. (2003). Detection of differences in the nucleotide and amino acid sequences of diphtheria toxin from Corynebacterium diphtheriae and Corynebacterium ulcerans causing extrapharyngeal infections. J Clin Microbiol 41, 4848-4851.

Sing, A., Bierschenk, S. \& Heesemann, J. (2005). Classical diphtheria caused by Corynebacterium ulcerans in Germany: amino acid sequence differences between diphtheria toxins from Corynebacterium diphtheriae and C. ulcerans. Clin Infect Dis 40, 325-326.

Tasman, A. \& Van Ramhorst, J. D. (1951). On the relation between toxin production and protein synthesis by Corynebacterium diphtheriae and the iron content of the culture medium. Antonie van Leeuwenhoek 17, 153-158.

Taylor, D. J. \& Efstratiou, A. (2002). Diphtheria toxin production by Corynebacterium ulcerans from cats. Vet Rec 150, 355.

Tchorbanov, A. I., Dimitrov, J. D. \& Vassilev, T. L. (2004). Optimization of casein-based semisynthetic medium for growing of toxigenic Corynebacterium diphtheriae in a fermenter. Can J Microbiol 50, 821-826.

Tiwari, T. S. P., Golaz, A., Yu, D. T., Ehresmann, K. R., Jones, T. F., Hill, H. E., Cassiday, P. K., Pawloski, L. C., Moran, J. S. \& other authors (2008). Investigations of 2 cases of diphtheria-like illness due to toxigenic Corynebacterium ulcerans. Clin Infect Dis 46, 395-401.

Von Hunolstein, C., Alfarone, G., Scopetti, F., Pataracchia, M., La Valle, R., Franchi, F., Pacchiani, L., Manera, A., Giammanco, A. \& other authors (2003). Molecular epidemiology and characteristics of Corynebacterium diphtheriae and Corynebacterium ulcerans strains isolated in Italy during the 1990s. J Med Microbiol 52, 181-188.

Wagner, J., Ignatius, R., Voss, S., Höpfner, V., Ehlers, S., Funke, G., Weber, U. \& Hahn, H. (2001). Infection of the skin caused by Corynebacterium ulcerans and mimicking classical cutaneous diphtheria. Clin Infect Dis 33, 1598-1600. 